\title{
Direct methane and nitrous oxide emissions of monogastric livestock in South Africa
}

\author{
C.J.L. du Toit ${ }^{1,2 \#}$, W.A. van Niekerk ${ }^{2}$ \& H.H. Meissner ${ }^{3}$ \\ ${ }^{1}$ Department of Animal Science, Tshwane University of Technology, Private Bag X680, Pretoria, 0001, South Africa \\ ${ }^{2}$ Department of Animal and Wildlife Sciences, University of Pretoria, 0002, South Africa \\ ${ }^{3} 189$ van Riebeeck Avenue, Lyttelton Manor, Centurion, 0157, South Africa
}

Copyright resides with the authors in terms of the Creative Commons Attribution 2.5 South African Licence.
See: http://creativecommons.org/licenses/by/2.5/za
Condition of use: The user may copy, distribute, transmit and adapt the work, but must recognise the authors and the South African Journal of Animal
Science.

\begin{abstract}
There are increasing concerns about the impact of agriculture and livestock production on the environment. In this the greenhouse gas emissions (GHG) from South African pigs, ostriches, horses, donkeys, mules and poultry were calculated, using 2010 production data on a provincial basis. The Intergovernmental Panel on Climate Change (IPCC) methodology adapted to tropical production systems was used to calculate methane $\left(\mathrm{CH}_{4}\right)$ and nitrous oxide $\left(\mathrm{N}_{2} \mathrm{O}\right)$ emissions. The non-ruminant sector is a minor GHG contributor compared with ruminant $\mathrm{CH}_{4}$ and $\mathrm{N}_{2} \mathrm{O}$ emissions. The pig industry and ostrich industry both contribute approximately $8 \mathrm{Gg}$ (Giga gram) $\mathrm{CH}_{4}$ /year. The poultry industry is the largest direct $\mathrm{N}_{2} \mathrm{O}$ producer of the non-ruminant livestock industries, contributing $2.3 \mathrm{Gg} /$ year or $92.8 \%$ of the total nonruminant $\mathrm{N}_{2} \mathrm{O}$ emissions.
\end{abstract}

Keywords: Greenhouse gas, pigs, horses, ostriches, broiler, layer

\#Corresponding author: dutoitcjl@tut.ac.za

\section{Introduction}

Livestock production systems contribute directly and indirectly to atmospheric anthropogenic greenhouse gases (GHG) through the emissions of carbon dioxide $\left(\mathrm{CO}_{2}\right)$, methane $\left(\mathrm{CH}_{4}\right)$ and nitrous oxide $\left(\mathrm{N}_{2} \mathrm{O}\right)$. The agricultural sector, including livestock, forest land and cropland (carbon sinks), wetlands and emissions from biomass burning in South Africa, contributes an estimated $4.7 \%$ to the total national GHG emissions (DEAT, 2009). This places agriculture third after the energy sector (79\%) and industrial processes (14\%) in terms of GHG emissions (DEAT, 2009). Livestock was reported to contribute $98 \%$ of the agricultural sector's methane emissions (Otter, 2010), making livestock a key methane emitting source, producing approximately $27.4 \%$ of national methane emissions. Methane and nitrous oxide are both potent GHG with 21 to 25 times and 298 to 310 times the global warming potential of carbon dioxide for methane and nitrous oxide, respectively (FAO, 2006; IPCC, 2006; Eckard et al., 2010).

An inventory methodology should follow international guidelines, as developed by the Intergovernmental Panel on Climate Change (IPCC, 2006) to ensure consistency and comparability between inventories and countries (Exnerova \& Cienciala, 2009). The IPCC followed a hierarchical approach of Tier 1 through to Tier 3 methodologies. Tier 1 methods are the crudest methodology, characterized by simple calculations based on aggregated statistical data and the use of developed default emission factors. Tier 2 methods are based on more detailed statistical data and emission factors derived from calculations using country-specific inputs. Finally, the Tier 3 method is the most sophisticated, requiring country-specific emission factors developed through direct measurements carried out under local or regional conditions (Exnerova \& Cienciala, 2009).

Greenhouse gas emissions from livestock vary by animal type, growth stage and level of production owing to different diets (diet quality, digestibility and forage: concentrate ratio), feed conversion mechanisms and manure management systems (Chadwick et al., 2000; Borhan et al., 2012; Zervas \& 
Tsiplakou, 2012). Emissions from animal manure and waste management systems are influenced by soil and manure moisture, temperature, manure loading rate by the animal, depth of manure in the pen, redox potential, available carbon, diets and microbial processes (Borhan et al., 2012). Ruminants are the main methane contributors in the livestock industry owing to their digestive process in which carbohydrates are degraded by micro-organisms and methane is released as a by-product of enteric fermentation (Stevens \& Hume, 1995; Wang \& Huang, 2005). Non-ruminants also contribute to methane emissions through enteric fermentation in the large intestine, but in much smaller quantities than ruminants (Wang \& Huang, 2005). Nitrous oxide is produced during the biological transformation of mineral nitrogen $(\mathrm{N})$ through nitrification, which converts ammonium $\left(\mathrm{NH}_{4}{ }^{+}\right)$nitrogen into nitrate $\left(\mathrm{NO}_{3}{ }^{-}\right)$, and denitrification, which reduces nitrate to molecular nitrogen $\left(\mathrm{N}_{2}\right)$. According to Duval \& Paquin (2009) denitrification produces approximately $10 \%$ more $\mathrm{N}_{2} \mathrm{O}$ than nitrification per unit of transformed nitrogen.

Previous inventories documenting GHG emissions from South African livestock (Blignaut et al., 2005; DEAT, 2009; Otter, 2010) were conducted on a national scale, utilizing IPCC default values (Tier 1 approach) for some or all of their emission calculations. These emission factors do not distinguish effectively between classes of animals, production efficiencies and production systems. They are often based on assumptions of animals utilizing highly digestible diets and temperate forages (Mills et al., 2001), which are not representative of South African production systems.

It is essential to obtain accurate estimates of GHG emissions from all sources in livestock production systems (animals, intensive housing, pens and kraals, manure handling facilities, silage bunkers, grazing lands, etc.) to improve emissions inventories and to develop source and country-specific abatement strategies. The objective of this paper is to review the methane and nitrous oxide emissions related to nonruminant livestock in South Africa in total as well as per province, using the Tier 2 approach.

\section{Materials and Methods}

The methodology was based on the Australian national greenhouse accounts, National Inventory Report (ANIR, 2009), which contains Australian country-specific and IPCC default methodologies and emission factors. A Tier 2 approach has been adopted for pig emission calculations in accordance with the IPCC (2006) good practice requirements. The emissions from ostriches, horses, donkeys, mules and poultry were calculated on a Tier 1 approach owing to a lack of activity data and the relatively small contribution of these animal categories. The inventory was compiled on a provincial basis where possible to reduce errors associated with averaging input data across areas with large physical and managerial differences. The provincial totals are aggregated to give national totals. The inventory was based on 2010 population data.

Non-ruminants (e.g. pigs, horses, mules, ostriches and poultry) do produce enteric methane in the large intestine, but the amount of methane produced is significantly less on a per animal basis than ruminants (EPA, 2013). The amount of enteric methane produced is influenced by the animal's digestive system, feed quality and the feed intake. The population numbers for all non-ruminant livestock in South Africa are based on figures provided by the Abstract of Agricultural Statistics (StatsSA, 2010), Department of Agriculture, Forestry and Fishery statistics (DAFF, 2010) and industry associations (SAPPO, 2011; NOPSA, 2011; SAPA, 2011). These figures were cross-referenced with slaughter and production data (SAPPO, 2011; NOPSA, 2011; SAPA, 2011).

The population numbers for commercial and communal (emerging and subsistence) pigs were calculated from the number of sows per province according to the average composition of a 100-sow unit as presented in Table 1 (SAPPO, 2011). To accommodate the use of artificial insemination in commercial pig production systems the number of breeding boars was reduced from 6 to 3 per 100 sow unit (Table 1).

Pigs are typically fed concentrate-based diets, especially in the commercial sector, and convert approximately $1 \%$ of gross energy intake (GEI) into methane compared with $6 \%$ - $7 \%$ for cattle and sheep (OECD, 1991). Methane conversion values for pigs are reported to be between $0.4 \%$ and $1.2 \%$ (Kirchgessner et al., 1991; Moss, 1993). A methane conversion factor of $0.7 \%$ was used in the calculation for pigs based on the ANIR (2009). Daily intake and diet data for all classes of commercial and communal pigs were sourced from SAPPO (2011).

The total daily methane production (M), $\left(\mathrm{kg} \mathrm{CH}_{4} /\right.$ head/day) from enteric fermentation in pigs was calculated based on the ANIR (2009) as: 
$\mathrm{M}=\mathrm{I} \times 18.6 \times 0.007 / \mathrm{F}$ Equation 1

Where: $\quad I=$ intake $(\mathrm{kg} \mathrm{DM} /$ day) (Appendix A.1)

$\mathrm{F}=55.22 \mathrm{MJ} / \mathrm{kg} \mathrm{CH}$ (Brouwer, 1965)

18.6 = MJ GE/kg feed dry matter (DM).

Table 1 Composition of a 100 sow pig unit in South Africa (SAPPO, 2011)

\begin{tabular}{lcc}
\hline & $\begin{array}{c}\text { Commercial production } \\
\text { systems }\end{array}$ & $\begin{array}{c}\text { Communal production } \\
\text { systems }\end{array}$ \\
\hline Boars & 3 & 6 \\
Dry gestating sows & 90 & 90 \\
Lactating sows & 16 & 16 \\
Replacement sows & 25 & 25 \\
Replacement boars & 3 & 3 \\
Pre-wean piglets & 160 & 80 \\
Cull sows & 25 & 25 \\
Cull boars & 3 & 3 \\
\hline
\end{tabular}

The enteric methane emission factors from all other non-ruminant or monogastric livestock, including ostriches (5 $\mathrm{kg} \mathrm{CH} /$ head/year), horses (18 $\mathrm{kg} \mathrm{CH}_{4} /$ head/year), donkeys and mules (10 kg $\mathrm{CH}_{4} /$ head/year), were sourced from the IPCC (2006), and the total methane emissions were calculated using population data and an annual methane emission factor. These emission factors are based on the work of Crutzen et al. (1986), who reported values for developing and developed countries and values recorded in the ANIR (2009). Currently an enteric methane emission factor is not reported for poultry (broilers or layers) in the IPCC (2006) good practice guidelines.

\section{Manure emissions}

The management of livestock manure can produce anthropogenic methane and nitrous oxide emissions (EPA, 2013). Commercial pig production systems in South Africa are housed systems, and a large proportion of manure and waste is managed in lagoon systems. These lagoon systems create anaerobic conditions, resulting in a high proportion of the volatile solids being fermented, which leads to the production of methane (ANIR, 2009). The volatile solid production (VS), (kg/head/day) from pig manure was calculated according to the IPCC (2006) as:

$\mathrm{VS}=[\mathrm{GE} \times(1-(\mathrm{DE} \% / 100))+(\mathrm{UE} \times \mathrm{GE})] \times[(1-\mathrm{Ash}) / 18.45]$ Equation 2

Where: $\quad$ GE $=$ gross energy intake $(\mathrm{MJ} /$ day) DE\% = digestibility of feed (\%) (Appendix A.1)

$(\mathrm{UE} \times \mathrm{GE})$ = urinary energy expressed as a fraction of GE. (Typically 0.02GE for pigs, IPCC, 2006)

Ash = ash concentration of manure (17\%), (F.K. Siebrits, 2012, Pers. Comm., Dept. Animal Science, Tshwane University of Technology, Private Bag X680, Pretoria, 0001)

18.45 = conversion factor for dietary GE per $\mathrm{kg}$ of $\mathrm{DM}(\mathrm{MJ} / \mathrm{kg})$.

Methane produced from manure $(\mathrm{M}),(\mathrm{kg} / \mathrm{head} / \mathrm{day})$ and wasted feed was calculated according to the ANIR (2009) as:

$M=V S \times B_{0} \times$ MCF $\times p$. Equation 3

Where: $\quad$ VS $=$ volatile solid production $(\mathrm{kg} / \mathrm{head} /$ day $)$ $\mathrm{B}_{\mathrm{o}}=$ emissions potential $\left(0.45 \mathrm{~m}^{3} \mathrm{CH}_{4} / \mathrm{kg}\right.$ VS) (IPCC 2006) 
MCF = integrated methane conversion factor. Based on the different manure management systems (Appendix A.3)

$p=$ density of methane $\left(0.662 \mathrm{~kg} / \mathrm{m}^{3}\right)$

Volatile solid production from poultry production systems was calculated based on the ANIR (2009) utilizing intake data and diet dry matter digestibilities as:

$\mathrm{VS}=\mathrm{I} \times(1-\mathrm{DMD}) \times(1-$ Ash $)$..... Equation 4

Where $=$

VS = volatile solid production $(\mathrm{kg} / \mathrm{head} /$ day $)$

$\mathrm{I}=$ dry matter intake (assumed to be $0.11 \mathrm{~kg} /$ day), (ANIR, 2009)

DMD = dry matter digestibility (assumed to be 80\%), (ANIR, 2009)

Ash $=$ ash concentration (assumed to be $8 \%$ of faecal DM), (ANIR, 2009)

Methane production from poultry manure (M) (kg/head/day) was calculated according to Equation 3, using a MCF of $1.5 \%$ according to the IPCC (2006). Ostriches, horses, donkeys and mules are kept on the veld in extensive systems with a relatively small amount of methane being produced from manure. Methane production from manure $(\mathrm{M})(\mathrm{kg} / \mathrm{head} /$ day) originating from these sources was calculated as:

$\mathrm{M}=\mathrm{DMM} \times \mathrm{MEF}$

Equation 5

Where: $\quad$ DMM $=$ dry matter in manure (Appendix A.5.2)

$\mathrm{MEF}=$ manure emission factor $\left(\mathrm{kg} \mathrm{CH}_{4} / \mathrm{kg}\right.$ DM manure) taken as $1.4 \times 10^{-5} \mathrm{~kg} \mathrm{CH}_{4} / \mathrm{kg}$

DMM (Gonzalez-Avalos \& Ruiz-Suarez, 2001).

The nitrous oxide emissions from pig production systems were calculated according to ANIR (2009). The annual nitrogen (AE, kg/year) from pig manure and wasted feed was calculated as:

$\mathrm{AE}=\mathrm{N} \times \mathrm{E}$

Equation 6

Where:

$\mathrm{N}=$ number of each category of pigs per province

$\mathrm{E}=$ nitrogen in waste $(\mathrm{kg} / \mathrm{head} /$ year $)$ (Appendix A.5.1 and A.6.1)

The total nitrous oxide emission (E), (kg) from pigs was calculated as:

$\mathrm{E}=\left(\mathrm{AE} \times \mathrm{MMS} \times \mathrm{EF} \times \mathrm{C}_{\mathrm{g}}\right)$

Equation 7

Where: $\quad$ MMS $=$ the fraction of $\mathrm{AE}$ that is managed in the different manure management systems (Appendix A.3)

$\mathrm{EF}=$ emission factor $\left(\mathrm{N}_{2} \mathrm{O}-\mathrm{N} \mathrm{kg} / \mathrm{N}\right.$ excreted) to the different MMS (Appendix A.6.2)

$\mathrm{C}_{\mathrm{g}}=44 / 28$ factor to convert the elemental mass of $\mathrm{N}_{2} \mathrm{O}$ to molecular mass.

The nitrogen excretion from poultry was calculated based on the ANIR (2009) using the average intake for broilers and layers ( $0.11 \mathrm{~kg} \mathrm{DM} / \mathrm{head} /$ day), with approximately $19 \%$ crude protein for broilers and $16.5 \%$ for layers. According to the NRC (1994), poultry are assumed to retain $43 \%$ of nitrogen intake, which gives a nitrogen excretion rate of $0.7 \mathrm{~kg} \mathrm{~N} / \mathrm{bird} /$ year and $0.6 \mathrm{~kg} \mathrm{~N} / \mathrm{bird} / \mathrm{year}$ for broilers and layers, respectively. The total $\mathrm{N}_{2} \mathrm{O}$ emissions from the various poultry production systems were then calculated using Equation 7 and assuming an emission factor of $0.02 \mathrm{~kg} \mathrm{~N} 2 \mathrm{O}-\mathrm{N} / \mathrm{kg} \mathrm{N}$ excreted for broilers and $0.005 \mathrm{~kg}$ $\mathrm{N}_{2} \mathrm{O}-\mathrm{N} / \mathrm{kg} \mathrm{N}$ excreted for layer chickens according to the ANIR (2009).

The direct nitrogen excretion rate for all other non-ruminant or monogastric livestock (ostriches, horses, donkeys and mules) was based on a ratio of the nitrogen excretion rates of sheep and cattle and animal size (ANIR, 2009). The nitrogen excretion rates are presented in Table A.5.3 in Appendix A. The nitrogen excreted by these livestock categories was calculated according to Equation 6 and the total $\mathrm{N}_{2} \mathrm{O}$ emissions from the various manure management systems were calculated according to Equation 7 . It was assumed that $40 \%$ of horse manure was managed in a drylot system and $60 \%$ was voided while the animals were at pasture. All manure from ostriches, donkeys and mules were assumed to be voided while the animals were at pasture. Emissions of $\mathrm{N}_{2} \mathrm{O}$ from soils related to livestock production systems are not included in the present review. These emissions arise from microbial and chemical transformations that produce and 
consume $\mathrm{N}_{2} \mathrm{O}$ in soil. Nitrogen compounds can be added to soil through the application of animal wastes and sewage sludge to pastures, leaching from soils and surface runoff of $\mathrm{N}$ and subsequent denitrification in water bodies, and $\mathrm{N}_{2} \mathrm{O}$ through the metabolism of urine and faeces deposited directly on pastures or rangeland.

\section{Results and Discussion}

The amount of enteric methane produced by pigs is influenced largely by the fibre content of the diet and is significantly less than $\mathrm{CH}_{4}$ produced by ruminants on a per animal basis (EPA, 2013). Manure is the largest direct GHG emissions source in commercial and communal (emerging and subsistence) pork production systems. Liquid manure storage is the most common manure management practice in South African commercial pig production systems, representing 93.5\% of all manure management (SAPPO, 2011). The communal pig sector is based more on semi-intensive or extensive production systems, with manure being deposited on pasture (50\%) or stored in drylot systems (50\%) (SAPPO, 2011). The methane conversion factors (MCF) for liquid manure handling facilities are much higher than when manure is managed in a drylot system or spread on pastures with $90 \%$ and 35\% MCF for lagoons and slurries compared with $1.5 \%$ and $0.5 \%$ for drylot and daily spread of manure (ANIR, 2009).

The direct methane and nitrous oxide emission factors $(\mathrm{kg} / \mathrm{h}$ ead/year) for the pig industry were calculated using a Tier 2 approach and are presented in Tables 2 and 3. The emission factors were calculated according to an average herd structure (SAPPO, 2011), liveweight (A.T. Browne, 2012, Pers. Comm., Dept. Animal Science, Tshwane University of Technology, Private Bag X680, Pretoria, 0001) and intake (SAPPO, 2011) for commercial and communal pig production systems.

Lactating sows were the highest emitters of $\mathrm{CH}_{4}$ and $\mathrm{N}_{2} \mathrm{O}$, followed by replacement animals, dry gestating sows, boars and grower animals. Lactating sows had the highest nutrient requirements and intake, which explains the higher emission factors reported in Tables 2 and 3.

Table 2 Direct methane and nitrous oxide emissions factors for South African commercial pigs

\begin{tabular}{lcccc}
\hline & $\begin{array}{c}\text { Weight } \\
(\mathbf{k g})\end{array}$ & $\begin{array}{c}\text { Enteric } \mathbf{C H}_{4} \\
(\mathbf{k g} / \mathbf{h} / \text { year) }\end{array}$ & $\begin{array}{c}\text { Manure } \mathbf{C H}_{4} \\
(\mathbf{k g} / \mathbf{h} / \text { year) }\end{array}$ & $\begin{array}{c}\mathbf{N}_{2} \mathbf{O} \\
(\mathbf{k g} / \mathbf{h} / \mathbf{y e a r})^{*}\end{array}$ \\
\hline Boars & & & & \\
Dry gestating sows & 300 & 1.89 & 16.47 & 0.045 \\
Lactating sows & 350 & 2.15 & 18.71 & 0.064 \\
Replacement sows & 300 & 4.09 & 35.55 & 0.064 \\
Replacement boars & 135 & 2.41 & 20.96 & 0.038 \\
Pre-wean piglets & 135 & 2.41 & 20.96 & 0.038 \\
Cull sows & 9 & 0.43 & 3.74 & 0.034 \\
Cull boars & 325 & 1.55 & 13.47 & 0.064 \\
Porkers** & 325 & 1.89 & 16.47 & 0.045 \\
Baconers*** & 70 & 0.51 & 17.96 & 0.0084 \\
& 90 & 0.99 & 20.96 & 0.014 \\
\hline
\end{tabular}

* kg/head/year; ** Porkers slaughtered at 3 months age (90 days);

$* * *$ Baconers slaughtered at 5 months age (150 days).

The total and provincial emissions contributions of the pig industry are presented in Table 4. The South African pork industry produced an estimated 7.9 Giga gram $(\mathrm{Gg})$ of $\mathrm{CH}_{4}$ and $0.04 \mathrm{Gg}$ of $\mathrm{N}_{2} \mathrm{O}$ annually. The commercial pig sector is responsible for $7.64 \mathrm{Gg}$ of the industry's methane emissions (97\%) and $0.015 \mathrm{Gg}$ of the industry's $\mathrm{N}_{2} \mathrm{O}$ emissions (38.5\%). Fifty per cent of the commercial pig sector's methane emissions originated from North West, KwaZulu-Natal and Western Cape, with $17.5 \%, 16.4 \%$ and $15.7 \%$, respectively. The communal pig sector is dominated by Eastern Cape, contributing $50 \%$ of the sector's methane emissions with North West, KwaZulu-Natal and Western Cape each responsible for approximately $9 \%$ of the methane emissions, respectively. The communal pig sector is responsible for $3 \%$ of 
the industry methane emissions and produced approximately $0.024 \mathrm{Gg}$ or $61.5 \%$ of the industry's total direct $\mathrm{N}_{2} \mathrm{O}$ emissions. This is owing to the differences in manure management systems between the commercial and communal production systems (Appendix A.3) and the higher $\mathrm{N}$ emission factor of 0.02 compared with 0.001 (IPCC, 2006) for manure managed in drylot systems compared to lagoon or slurry systems.

In the previous livestock GHG inventory commissioned by the Department of Environmental Affairs and Tourism, which was based on 2004 data, the pork industry produced a total of $53.07 \mathrm{Gg}$ of $\mathrm{CH}_{4}$ and $0.891 \mathrm{Gg} \mathrm{N} \mathrm{N}_{2} \mathrm{O}$ emissions. These figures are higher than the current estimated figures reported in Table 4, of $7.87 \mathrm{Gg}$ for $\mathrm{CH}_{4}$ and $0.04 \mathrm{Gg}$ for $\mathrm{N}_{2} \mathrm{O}$, respectively. The previous inventory was conducted on a Tier 1 level, using IPCC default values for both methane and nitrous oxide emissions. There is a wide variation in population figures between the 2004 inventory and the current estimation. In the previous inventory, Otter (2010) based the population numbers on national statistics of approximately 2.6 million animals in 2004 (StatsSA, 2010).

Table 3 Direct methane and nitrous oxide emissions factors for South African communal pigs

\begin{tabular}{lcccc}
\hline & $\begin{array}{c}\text { Weight } \\
\text { (kg) }\end{array}$ & $\begin{array}{c}\text { Enteric CH } \\
\text { (kg/h/year) }\end{array}$ & $\begin{array}{c}\text { Manure CH } \\
\text { (kg/h/year) }\end{array}$ & $\begin{array}{c}\mathbf{N}_{\mathbf{2}} \mathbf{O} \\
\text { (kg/h/year) }^{*}\end{array}$ \\
\hline Boars & 240 & 1.55 & 0.37 & 0.23 \\
Dry gestating sows & 280 & 1.72 & 0.42 & 0.33 \\
Lactating sows & 240 & 3.27 & 0.79 & 0.33 \\
Replacement sows & 108 & 1.93 & 0.46 & 0.19 \\
Replacement boars & 108 & 1.93 & 0.46 & 0.19 \\
Pre-wean piglets & 7.2 & 0.34 & 0.08 & 0.17 \\
Cull sows & 260 & 1.24 & 0.30 & 0.33 \\
Cull boars & 260 & 1.55 & 0.37 & 0.23 \\
Porkers** & 70 & 0.41 & 0.40 & 0.042 \\
Baconers*** & 90 & 0.79 & 0.46 & 0.07 \\
\hline
\end{tabular}

* kg/head/year; ** Porkers slaughtered at 3 months age (90 days).

$* * *$ Baconers slaughtered at 5 months age (150 days).

The national statistics figures are not aligned with the population figures provided by the industry of approximately 600000 animals in commercial and communal production systems across all provinces in 2010 (SAPPO, 2011). The aggregated $\mathrm{CH}_{4}$ emissions (both enteric and manure) for all pigs were 20.73 $\mathrm{kg} / \mathrm{animal} /$ year in 2004 compared with $13.19 \mathrm{~kg} / \mathrm{animal} / \mathrm{year}$ estimated on a Tier 2 level in the current estimation of 2010. The annual $\mathrm{CH}_{4}$ emission per animal calculated in the current inventory (13.19 $\mathrm{kg} / \mathrm{animal} / \mathrm{year}$ ) is higher than emissions reported by Verge et al. (2009) for the Canadian pork industry of $7.9 \mathrm{~kg} \mathrm{CH} / \mathrm{animal} /$ year and $11.6 \mathrm{~kg} \mathrm{CH} /$ animal/year. The differences in the Canadian figures were mainly owing to differences in the diet digestibilities used in various regions (Verge et al., 2009).

The South African emission factors reported in Tables 2 and 3 are compared with emission factors developed by other developing and developed countries in Table 5. The estimated enteric emission factors for commercial and communal pigs are higher than the IPCC (2006) default factors for developing countries, but are comparable with default values reported for developed countries such as North America, Canada and Australia. The estimated commercial manure methane emission factors are in line with IPCC (2006) values for developed countries and Australian country-specific values, but higher than emission factors reported by New Zealand, Canada and India. These differences are probably owing to variations in animal liveweight, diet digestibility, intake and variations in manure management systems. The nitrogen excretion rate calculated for commercial and communal kept pigs in South Africa falls in the range of published data of 10.8 to $20.7 \mathrm{~kg}$ N/animal/year as reported in Table 5 .

Greenhouse gas emissions reported from poultry production systems in South Africa are mainly methane and nitrous oxide emissions from manure. The IPCC (2006) does not include enteric methane 
emissions from poultry in emissions inventories, although Wang \& Huang (2005) and Burns et al. (2008) did report on enteric methane emissions for broiler chickens of $3.77 \times 10^{-7} \mathrm{~kg} / \mathrm{bird} /$ day (42 day growth period) and $6.56 \times 10^{-5} \mathrm{~kg} / \mathrm{bird} /$ day (52-day growth period), respectively. The poultry emissions were calculated based on the IPCC (2006) Tier 1 approach using emissions factors reported in the ANIR (2009) for all classes of chickens (broilers, broiler parents, layers, and layer breeders). The methane and $\mathrm{N}_{2} \mathrm{O}$ emission factors for South African broiler and layer production systems are presented in Table 6. A 34 day growth

Table 4 Provincial greenhouse gas emissions summary of South African pigs based on 2010 data (Gg/year)

\begin{tabular}{lcccccccc}
\hline \multirow{2}{*}{ Province } & \multicolumn{4}{c}{ Commercial } \\
\cline { 2 - 9 } & Population & $\begin{array}{c}\text { Enteric } \\
\text { methane }\end{array}$ & $\begin{array}{c}\text { Manure } \\
\text { methane }\end{array}$ & $\mathbf{N}_{\mathbf{2}} \mathbf{O}$ & Population & $\begin{array}{c}\text { Enteric } \\
\text { methane }\end{array}$ & $\begin{array}{c}\text { Manure } \\
\text { methane }\end{array}$ & $\mathbf{N}_{\mathbf{2}} \mathbf{O}$ \\
\hline Gauteng & 51895 & 0.09 & 0.77 & $1.6 \times 10^{-3}$ & 7216 & 0.011 & 0.003 & $1.4 \times 10^{-3}$ \\
Limpopo & 53350 & 0.09 & 0.79 & $1.7 \times 10^{-3}$ & 7544 & 0.011 & 0.003 & $1.5 \times 10^{-3}$ \\
Mpumalanga & 64020 & 0.11 & 0.94 & $2 \times 10^{-3}$ & 8856 & 0.013 & 0.003 & $1.7 \times 10^{-3}$ \\
North West & 81480 & 0.14 & 1.20 & $2.6 \times 10^{-3}$ & 11152 & 0.016 & 0.004 & $2.2 \times 10^{-3}$ \\
KZN & 76145 & 0.13 & 1.12 & $2.4 \times 10^{-3}$ & 10496 & 0.016 & 0.004 & $2 \times 10^{-3}$ \\
W Cape & 73235 & 0.12 & 1.08 & $2.3 \times 10^{-3}$ & 10168 & 0.015 & 0.004 & $2 \times 10^{-3}$ \\
Free State & 41225 & 0.07 & 0.61 & $1.3 \times 10^{-3}$ & 5576 & 0.008 & 0.002 & $1.1 \times 10^{-3}$ \\
Eastern Cape & 21340 & 0.04 & 0.31 & $6.7 \times 10^{-4}$ & 61992 & 0.092 & 0.022 & $1.2 \times 10^{-2}$ \\
N Cape & 9215 & 0.02 & 0.02 & $2.9 \times 10^{-4}$ & 1640 & 0.002 & 0.0006 & $3.2 \times 10^{-4}$ \\
Total & 471905 & 0.8 & 6.84 & 0.015 & 124640 & 0.184 & 0.044 & 0.024 \\
& & & & & & & &
\end{tabular}

W Cape: Western Cape; N Cape: Northern Cape; KZN: KwaZulu-Natal.

Table 5 Comparison of calculated and published emission factors for pork from international sources

\begin{tabular}{|c|c|c|c|c|c|}
\hline \multirow[b]{2}{*}{ Source } & & \multicolumn{2}{|c|}{ Methane } & \multirow{2}{*}{$\begin{array}{c}\begin{array}{c}\text { Nitrogen } \\
\text { excretion rate } \\
\text { (kg/head/year) }\end{array} \\
\end{array}$} & \multirow[b]{2}{*}{ Reference } \\
\hline & & $\begin{array}{c}\text { Enteric } \\
\text { (kg/head/year) }\end{array}$ & $\begin{array}{c}\text { Manure } \\
\text { (kg/head/year) }\end{array}$ & & \\
\hline \multirow[t]{2}{*}{ South Africa } & Commercial & 1.8 & 18.5 & 14.9 & \\
\hline & Communal & 1.5 & 0.41 & 14.9 & \\
\hline \multirow[t]{2}{*}{ IPCC: Africa } & Developed & 1.5 & 1.0 & & a \\
\hline & Developing & 1.0 & 1.0 & & \\
\hline \multirow[t]{2}{*}{ IPCC: Oceania } & $\begin{array}{l}\text { Breeding } \\
\text { swine }\end{array}$ & 1.5 & 23.0 & 20.0 & \\
\hline & Market swine & 1.5 & 13.0 & 16.0 & \\
\hline \multirow[t]{2}{*}{$\begin{array}{l}\text { IPCC: North } \\
\text { America }\end{array}$} & $\begin{array}{l}\text { Breeding } \\
\text { swine }\end{array}$ & 1.5 & 28.0 & & \\
\hline & Market swine & 1.5 & 15.0 & & \\
\hline Australia & & 1.45 & 23.0 & 20.7 & $\mathrm{~b}$ \\
\hline New Zealand & & 1.08 & 5.94 & 10.8 & c \\
\hline Brazil & & 1.0 & 1.0 & & $\mathrm{~d}$ \\
\hline Canada & & 1.5 & $10-10.4$ & & e \\
\hline India & & & $4.37-4.50$ & & $\mathrm{f}$ \\
\hline
\end{tabular}

a: IPCC (2006); b: ANIR (2009); c: NZNIR (2010); d: Lima et al. (2002); e: Kebreab et al. (2006);

f: Chhabra et al. (2012). 
period was assumed for broiler production systems in South Africa with an average of eight production cycles per year (A.F. Hill, 2013, Pers. Comm., Rainbow chicken contract grower, P.O. Box 2734, Westville, 3635).

Table 6 Methane and nitrous oxide emission factors of South African poultry (ANIR, 2009)

\begin{tabular}{lccc}
\hline & $\begin{array}{c}\text { Enteric } \mathbf{C H}_{\mathbf{4}} \\
\text { (kg/head/year)* }\end{array}$ & $\begin{array}{c}\text { Manure } \mathbf{C H}_{\mathbf{4}} \\
\text { (kg/head/year) }\end{array}$ & $\begin{array}{c}\mathbf{N}_{\mathbf{2}} \mathbf{O} \\
\text { (kg/head/year) }\end{array}$ \\
\hline Layers & 0 & 0.0235 & 0.003 \\
Layer breeders & 0 & 0.0235 & 0.003 \\
Broilers & 0 & 0.0235 & 0.014 \\
Broiler breeders & 0 & 0.0235 & 0.014 \\
& & & \\
* Enteric methane emissions reported for broilers from different sources of 3.77 x 10 & $\mathrm{kg} / \mathrm{bird} /$ day \\
\# Wang \& Huang, 2005) and 6.56 x 10 ${ }^{-5} \mathrm{~kg} /$ bird/day (Burns et al., 2008) were not incorporated. \\
\# Representing direct $\mathrm{N}_{2} \mathrm{O}$ emissions.
\end{tabular}

Similar daily DM intakes (0.11 kg/day) and diet DMD (80\%) were assumed for both broiler and layer production systems, which resulted in a single manure methane emission factor ( $\mathrm{kg} / \mathrm{head} / \mathrm{day})$ for the poultry industry. Broilers have higher protein requirements when compared to layers (NRC, 1994), which explains the slightly higher $\mathrm{N}_{2} \mathrm{O}$ emission factor for both broilers and broiler parents compared to layers.

The population data for all classes of poultry in South Africa were sourced from SAPA (2011) which combined the figures of Western Cape and Northern Cape provinces and Mpumalanga and Limpopo. For the purpose of this inventory the combined population figures were equally divided between the two provinces in question. The provincial contributions to poultry GHG emissions are presented in Tables 7 and 8. Poultry emissions estimated are only based on population figures for the commercial poultry industry as no data on poultry in communal production systems exist for South Africa.

Table 7 Provincial direct greenhouse gas emissions (Gg/year) summary of South African broilers (2010)

\begin{tabular}{|c|c|c|c|c|c|c|c|c|}
\hline \multirow[b]{2}{*}{ Province } & \multicolumn{4}{|c|}{ Broiler } & \multicolumn{4}{|c|}{ Broiler breeders } \\
\hline & $\begin{array}{c}\text { Population } \\
\text { ('000) }\end{array}$ & $\begin{array}{c}\text { Enteric } \\
\text { methane }\end{array}$ & $\begin{array}{l}\text { Manure } \\
\text { methane }\end{array}$ & $\mathbf{N}_{2} \mathbf{O}$ & $\begin{array}{c}\text { Population } \\
\text { ('000) }\end{array}$ & $\begin{array}{c}\text { Enteric } \\
\text { methane }\end{array}$ & $\begin{array}{l}\text { Manure } \\
\text { methane }\end{array}$ & $\mathbf{N}_{2} \mathbf{O}$ \\
\hline W Cape* & 10897 & 0 & 0.256 & 0.24 & 709 & 0 & 0.017 & 0.016 \\
\hline Eastern Cape & 6850 & 0 & 0.161 & 0.15 & 448 & 0 & 0.011 & 0.010 \\
\hline N Cape* & 10897 & 0 & 0.256 & 0.24 & 709 & 0 & 0.017 & 0.016 \\
\hline KZN & 16309 & 0 & 0.383 & 0.36 & 1061 & 0 & 0.025 & 0.023 \\
\hline Free State & 5658 & 0 & 0.133 & 0.12 & 365 & 0 & 0.009 & 0.008 \\
\hline North West & 25713 & 0 & 0.604 & 0.57 & 1674 & 0 & 0.04 & 0.037 \\
\hline Gauteng & 5658 & 0 & 0.133 & 0.12 & 365 & 0 & 0.009 & 0.008 \\
\hline Mpumalanga* & 11940 & 0 & 0.281 & 0.26 & 778 & 0 & 0.018 & 0.017 \\
\hline Limpopo* & 11940 & 0 & 0.281 & 0.26 & 778 & 0 & 0.018 & 0.017 \\
\hline Total & 105860 & 0 & 2.49 & 2.33 & 6888000 & 0 & 0.162 & 0.152 \\
\hline
\end{tabular}

* Population numbers are combined in literature and were divided equally.

W Cape: Western Cape; N Cape: Northern Cape; KZN: KwaZulu-Natal. 
The broiler industry is responsible for $81 \%$ of the poultry industry's methane emissions and $95 \%$ of the industry's $\mathrm{N}_{2} \mathrm{O}$ emissions of $3.28 \mathrm{Gg}$ and $2.6 \mathrm{Gg}$ for $\mathrm{CH}_{4}$ and $\mathrm{N}_{2} \mathrm{O}$, respectively. North West and KwaZulu-Natal were the biggest sole broiler producing provinces with $24.3 \%$ and $15.4 \%$ respectively of the national broiler population. The largest population of layers were found in Gauteng and the Free State, with $21 \%$ and 14.8\%, respectively. If enteric emission factors reported by Burns et al. (2008) are incorporated into the emissions estimation for both broilers and layers, the total methane emissions from poultry production systems are increased by $68 \%$ to $5.8 \mathrm{Gg} /$ year compared with $3.28 \mathrm{Gg} /$ year, respectively.

The manure emission factors adopted for the present inventory are compared with international sources in Table 9. The emission factors utilized in the current emissions estimation fall within the range of international figures reported in Table 9.

Table 8 Provincial direct greenhouse gas emissions (Gg/year) summary of South African layers (2010)

\begin{tabular}{lcccccccl}
\hline \multirow{2}{*}{ Province } & \multicolumn{4}{c}{ Commercial } \\
\cline { 2 - 9 } & $\begin{array}{c}\text { Population } \\
(\mathbf{( 0 0 0 )}\end{array}$ & $\begin{array}{c}\text { Enteric } \\
\mathbf{C H}_{\mathbf{4}}\end{array}$ & $\begin{array}{c}\mathbf{M a n u r e} \\
\mathbf{C H}_{\mathbf{4}}\end{array}$ & $\mathbf{N}_{\mathbf{2}} \mathbf{O}$ & $\begin{array}{c}\text { Population } \\
\mathbf{( ' \mathbf { 0 0 0 } )}\end{array}$ & $\begin{array}{c}\text { Enteric } \\
\mathbf{C H}_{\mathbf{4}}\end{array}$ & $\begin{array}{c}\text { Manure } \\
\mathbf{C H}_{\mathbf{4}}\end{array}$ & $\mathbf{N}_{\mathbf{2}} \mathbf{O}$ \\
\hline W Cape* & 2596 & 0 & 0.06 & 0.012 & 29 & 0 & $7 \times 10^{-4}$ & 0.000139 \\
Eastern Cape & 910 & 0 & 0.02 & 0.004 & 10 & 0 & $2 \times 10^{-4}$ & $4.81 \times 10^{-5}$ \\
N Cape* & 2596 & 0 & 0.06 & 0.012 & 29 & 0 & $7 \times 10^{-4}$ & 0.000139 \\
KZN & 3670 & 0 & 0.09 & 0.017 & 42 & 0 & $1 \times 10^{-3}$ & 0.000197 \\
Free State & 4672 & 0 & 0.11 & 0.022 & 53 & 0 & $1.2 \times 10^{-3}$ & 0.00025 \\
North West & 2584 & 0 & 0.06 & 0.012 & 29 & 0 & $7 \times 10^{-4}$ & 0.000139 \\
Gauteng & 6596 & 0 & 0.16 & 0.031 & 75 & 0 & $1.8 \times 10^{-3}$ & 0.000352 \\
Mpumalanga* & 1415 & 0 & 0.03 & 0.007 & 16 & 0 & $4 \times 10^{-4}$ & $7.57 \times 10^{-5}$ \\
Limpopo* & 1415 & 0 & 0.03 & 0.007 & 16 & 0 & $4 \times 10^{-4}$ & $7.57 \times 10^{-5}$ \\
Total & 26454 & 0 & 0.62 & 0.125 & 300 & 0 & $7.1 \times 10^{-3}$ & 0.001414 \\
\end{tabular}

* Population numbers are combined in literature and were divided equally.

W Cape: Western Cape; N Cape: Northern Cape; KZN: KwaZulu-Natal.

Table 9 Methane and nitrous oxide emission factors from poultry manure (kg/bird/year)

\begin{tabular}{llcl}
\hline Source & $\begin{array}{c}\text { Methane } \\
\text { (kg/bird/year) }\end{array}$ & $\begin{array}{c}\text { Nitrogen excreted } \\
\text { (kg N/bird/year) }\end{array}$ & Reference \\
\hline South Africa - 2010 & 0.0235 & $0.6-0.7$ & \\
South Africa: 2004 & $0.02-0.03$ & $0.60-0.72$ & Otter, 2010 \\
IPCC: Africa & $0.02-0.03$ & $0.6-1.10$ & IPCC (2006) \\
IPCC: Oceania & $0.02-1.4$ & $0.6-1.10$ & IPCC (2006) \\
Australia & 0.02 & $0.6-0.7$ & ANIR (2009) \\
New Zealand & $0.016-0.022$ & $0.39-0.42$ & NZNIR (2010) \\
North America & 0.1 & & EPA (2013) \\
Brazil & $0.018-0.117$ & & Lima et al. (2002)
\end{tabular}

The other non-ruminant or monogastric livestock classes of horses, donkeys, mules and ostriches are minor contributors to the livestock industry's GHG emissions and a Tier 1 approach was followed, using emission factors reported by ANIR (2009). The emission factors (kg/head/year) are presented in Table 10. 
Table 10 Methane and nitrous oxide emission factors for other non-ruminant livestock in 2010

\begin{tabular}{lccc}
\hline Species & $\begin{array}{c}\text { Enteric } \mathbf{C H}_{\mathbf{4}} \\
\text { (kg/head/year) }\end{array}$ & $\begin{array}{c}\text { Manure } \mathbf{C H}_{\mathbf{4}} \\
\text { (kg/head/year) }\end{array}$ & $\begin{array}{c}\text { N excreted } \\
\text { (kg N/head/year) }\end{array}$ \\
\hline & 18 & 0.0134 & 39.5 \\
Horses & 10 & 0.0045 & 13.2 \\
Donkeys & 10 & 0.0045 & 13.2 \\
Mules & 5 & 0.0016 & 7.0 \\
Ostriches & & & \\
\hline
\end{tabular}

Table 11 Provincial direct greenhouse gas emissions summary of horses (2010)

\begin{tabular}{lcclc}
\hline Province & Population & $\begin{array}{c}\text { Enteric } \mathbf{C H}_{4} \\
\text { (Gg/year) }\end{array}$ & $\begin{array}{c}\text { Manure } \mathbf{C H}_{\mathbf{4}} \\
\text { (Gg/year) }\end{array}$ & $\begin{array}{c}\mathbf{N}_{\mathbf{2}} \mathbf{O} \\
(\mathbf{G g} / \text { year) }\end{array}$ \\
\hline Western Cape & 37125 & 0.67 & 0.0005 & 0.012 \\
Eastern Cape & 43470 & 0.78 & 0.0006 & 0.014 \\
Northern Cape & 43921 & 0.79 & 0.0006 & 0.014 \\
KwaZulu-Natal & 45009 & 0.81 & 0.0006 & 0.014 \\
Free State & 51435 & 0.93 & 0.0007 & 0.016 \\
North West & 22923 & 0.41 & 0.0003 & 0.007 \\
Gauteng & 4590 & 0.08 & $6.15 \times 10^{-5}$ & 0.0015 \\
Mpumalanga & 18333 & 0.33 & 0.00025 & 0.006 \\
Limpopo & 3159 & 0.06 & $4.23 \times 10^{-5}$ & 0.001 \\
Total & 269965 & 4.86 & 0.004 & 0.086 \\
\hline
\end{tabular}

The population figures for donkeys and mules were sourced from the FAO (2010). These species did not contribute direct $\mathrm{N}_{2} \mathrm{O}$ emissions to the national total as they are kept exclusively in extensive production systems where all manure is voided at pasture. The methane emissions for donkeys and mules are reported in Table 12.

Table 12 Methane emissions of donkeys and mules (2010)

\begin{tabular}{lcccc}
\hline Species & Population & $\begin{array}{c}\text { Enteric } \mathbf{C H}_{4} \\
\text { (Gg/year) }\end{array}$ & $\begin{array}{c}\text { Manure } \mathbf{C H}_{4} \\
\text { (Gg/year) }\end{array}$ & $\begin{array}{c}\text { Total } \mathbf{C H}_{4} \\
\text { (Gg/year) }\end{array}$ \\
\hline Donkeys & 150500 & 1.51 & 0.00067 & 1.51 \\
Mules & 14200 & 0.142 & $6.34 \times 10^{-5}$ & 0.142 \\
\hline
\end{tabular}

South Africa is the major supplier of ostrich products globally, and produces approximately $70 \%$ of all ostrich meat, leather and feathers to the world market (Brand \& Jordaan, 2011). Ostriches are commercially farmed mainly in Western Cape and Eastern Cape with 60\% of the ostrich population located in the Western Cape and 34\% in the Eastern Cape (NOPSA, 2011). The provincial GHG emission summary of the ostrich industry is presented in Table 13. Ostrich manure is deposited directly on to veld and there are no direct nitrous oxide emissions attributed to ostrich production systems according to the IPCC (2006) guidelines.

Previous inventories for the South African livestock sector did not include ostriches or other poultry as emission sources. Ducks, geese and turkeys are minor livestock categories that do not contribute 
significantly to GHG emissions and are not commonly included in emissions inventories (Lima et al., 2002; ANIR, 2009; NZNIR, 2010). The emission calculations for the other poultry categories were done on a Tier 1 basis using IPCC (2006) default values of $0.03 \mathrm{~kg} / \mathrm{bird} /$ year for duck and geese manure $\mathrm{CH}_{4}$ emissions and $0.09 \mathrm{~kg} / \mathrm{bird} /$ year for turkey manure $\mathrm{CH}_{4}$ emissions. An annual nitrogen excretion rate of 0.6 $\mathrm{kg} / \mathrm{bird} /$ year was assumed according to the IPCC (2006) with an emissions factor of $0.001 \mathrm{~kg} \mathrm{~N} \mathrm{~N}_{2} \mathrm{O}-\mathrm{N} / \mathrm{kg} \mathrm{N}$ excreted to calculate the $\mathrm{N}_{2} \mathrm{O}$ emissions for the above poultry classes. Population data were sourced from the FAO (2010) as 375000 ducks, 135000 geese and 515000 turkeys on a national scale. The estimated manure methane and nitrous oxide emissions ( $\mathrm{Gg} /$ year) for ducks, geese and turkey were $0.011,0.0041,0.05$ and $0.00023,0.00008$, and 0.00031 , respectively.

Table 13 Provincial methane emissions summary of the South African ostrich industry

\begin{tabular}{lrll}
\hline Province & Population & $\begin{array}{c}\text { Enteric } \mathbf{C H}_{\mathbf{4}} \\
\text { (Gg/year) }\end{array}$ & $\begin{array}{c}\text { Manure } \mathbf{C H}_{4} \\
\text { (Gg/year) }\end{array}$ \\
\hline Western Cape & 960000 & 4.8 & 0.00153 \\
Eastern Cape & 544000 & 2.72 & 0.00087 \\
Other & 96000 & 0.48 & 0.00015 \\
Total & 1600000 & 8.0 & 0.0026 \\
\hline
\end{tabular}

\section{Conclusion}

Globally, pigs, horses, ostriches and poultry are considered minor sources of GHG emissions contributing to total livestock emissions. A limited amount of research has been conducted to quantify direct emissions from these sources. The majority of published GHG emissions from pigs, equines and poultry are based on IPCC default values (Tier 1).The GHG contribution from non-ruminant (or monogastric) livestock in South Africa is minor compared with ruminant methane and $\mathrm{N}_{2} \mathrm{O}$ emissions. Non-ruminant livestock are responsible for a total of $25.7 \mathrm{Gg}$ methane emissions, with ostriches being the largest contributor, followed by pigs, horses, poultry and donkeys/mules with $31.1 \%, 30.6 \%, 18.9 \%, 12.8 \%$ and $6.4 \%$, respectively. The poultry industry is the largest direct $\mathrm{N}_{2} \mathrm{O}$ producer of the non-ruminant livestock industries with $2.25 \mathrm{Gg}$ or $92.8 \%$ of the total $\mathrm{N}_{2} \mathrm{O}$ emission originating from pigs, horses and poultry.

\section{Acknowledgement}

This work is based on the research supported wholly by the National Research Foundation of South Africa and the RMRD SA.

\section{References}

Australian National Inventory Report (ANIR), 2009. Australian national greenhouse accounts: National Inventory Report. Department of climate change and energy efficiency, Commonwealth of Australia, Canberra, ACT.

Blignaut, J.N., Chitiga-Mabugu, M.R. \& Mabugu, R.M., 2005. Constructing a greenhouse gas inventory using energy balances: the case of South Africa 1998. J. Energy S. Afr. 16, 21-32.

Borhan, S., Mukhtar, S., Capareda, S. \& Rahman, S., 2012. Greenhouse gas emissions from housing and manure management systems at confined livestock operations. In: Chapter 12, Waste management An integrated vision. http://dx.doi.org/10.5772/51175.

Brand, T.S. \& Jordaan, J.W., 2011. The contribution of the South African ostrich industry to the national economy. Appl. Anim. Husb. Rural Develop. 4, 1-7.

Brouwer, E., 1965. Report of sub-committee on constants and factors. In: Proceedings of the $3^{\text {rd }}$ Symposium on Energy Metabolism. Ed: Blaxter, K.L., London: Academic Press. pp. 441-443.

Burns, R.T., Li, H., Xin, H., Gates, R.S. \& Overhults, D.G., 2008. Greenhouse (GHG) emissions from broiler houses in the Southern United States. Presented at the ASABE Annual International meeting, Rhode Island, June 29-July 2, 2008. Paper no 084649. 
Chadwick, D.R., Pain, B.F. \& Brookman, S.K.E., 2000. Nitrous oxide and methane emissions following application of animal manures to grassland. J. Environ. Quality 29, 277-287.

Chhabra, A., Manjunath, K.R., Panigraphy, S. \& Parihar, 2012. Greenhouse gas emissions from Indian livestock. Climate change, 117, 329-344.

Crutzen, P.J., Aselmann, I. \& Seiler, W., 1986. Methane production by domestic animals, wild ruminants other herbivorous fauna and humans. Tellus 38B, 271-284.

DAFF, 2007. A profile of the South African market value chain, 2007. Directorate Marketing, Department of Agriculture, Forestry and Fisheries, Arcadia, Pretoria, South Africa.

DAFF, 2010. Livestock population statistics 2010. Department of Agriculture, Forestry and Fisheries, Pretoria, South Africa.

DEAT, 2009. Greenhouse gas inventory, South Africa. Communication under the United Nation Framework Convention on Climate Change. Department of Environmental Affairs and Tourism, Pretoria, South Africa.

Duval, C. \& Paquin, S., 2009. Swine production and greenhouse gases. Federation des producteurs de porcs du Quebec. Quebec, Canada.

Eckard, R.J., Grainger, C. \& De Klein, C.A.M., 2010. Options for the abatement of methane and nitrous oxide from ruminant production: A review. Livest. Sci. 130, 47-56.

EPA, 2013. Environmental Protection Agency - Inventory of U.S. greenhouse gas emissions and sinks: 1990 - 2011. Washington D.C. EPA. http://epa.gov/climatechange/emissions/downloads/ GHG2013entire_report-508.pdf.

Exnerova, Z. \& Cienciala, E., 2009. Greenhouse gas inventory of agriculture in the Czech Republic. Plant Soil Environ. 55, 311-319.

FAO, 2006. Food and Agriculture Organization of the United Nations, 2010. [Accessed on 5 March 2012]. FAOSTAT.

FAO, 2010. Food and Agriculture Organization of the United Nations, 2010. [Accessed on 5 March 2012]. FAOSTAT.

Gonzalez-Avalos, E. \& Ruiz-Suarez, L.G., 2001. Methane emission factors from cattle manure in Mexico. Biosecure Technol. 80, 63-71.

IPCC, 2006. IPCC guidelines for National Greenhouse Gas Inventories. Prepared by the National Greenhouse Gas Inventories Programme. Eds: Eggleston, H.S., Buendia, L., Miwa, K., Ngara, T. \& Tanabe, K., Published: IGES, Japan.

Kebreab, E., Clark, K., Wagner-Riddle, C. \& France, J., 2006. Methane and nitrous oxide emissions from Canadian animal agriculture: A review. Can. J. Anim. Sci. 86, 135-158.

Kirchgessner, M., Kreuzer, M., Muller, H.L. \& Windish, W., 1991. Release of methane and carbon dioxide by the pig. Agribiol. Res. 44, 103-113.

Lima, M.A., Young Pessoa, M.C.P. \& Vieira Ligo, M.A., 2002. Methane emissions from livestock. In: First Brazilian inventory of anthropogenic greenhouse gas emissions. Ministry of Science and Technology, Brazil.

Mills, J.A., Dijkstra, J., Bannik, A., Cammell, S.B., Krebreab, E. \& France, J., 2001. A mechanistic model of whole tract digestion and methanogenesis in the lactating dairy cow: Model development, evaluation and application. J. Anim. Sci. 79, 1584-1597.

Moss, A.R., 1993. Methane: global warming and production by animals. Chalcombe Publ., Kent, U.K.

New Zealand’s Greenhouse Gas Inventory, 2010. National Inventory Report (NZNIR) 1990 - 2010. http://www.mfe.govt.nz/publications/climate/nz-fifth-national-communication/html.

NOPSA, 2011. Report to authors on ostrich numbers and production data. National Ostrich Processors of South Africa, South Africa.

NRC, 1994. Nutrient Requirements of Poultry: Ninth revised edition, 1994. National Academy Press, Washington D.C., USA.

OECD, 1991. Estimation of GHG emissions and sinks. Final report from the OECD experts meeting 18 - 21 Feb 1991. The Organisation for Economic Co-operation and Development, Paris, France, Revised 1991.

Otter, L., 2010. The South African agricultural GHG inventory for 2004. Department of Agriculture, Forestry and Fisheries, South Africa. 
SAPA, 2011. Report to authors on poultry numbers. South African Poultry Association, Johannesburg, South Africa.

SAPPO, 2011. Report to authors on pig numbers in South Africa and production data. South African Pork Producers Organisation, Pretoria, South Africa.

STATS South Africa, 2010. Statistics South Africa: Abstract of Agricultural Statistics. Directorate: Agriculture Statistics, DAFF, Pretoria, South Africa.

Stevens, C.E. \& Hume, I.D., 1995. Comparative physiology of the vertebrate digestive system. Cambridge University Press, Cambridge, UK.

Verge, X.P.C., Dyer, J.A., Desjardins, R.L. \& Worth, D., 2009. Greenhouse gas emissions from the Canadian pork industry. Livest. Sci. 121, 82-101.

Wang, S. \& Huang, D., 2005. Assessment of greenhouse gas emissions from poultry enteric fermentation. Asian-Aust. J. Anim. Sci. 18, 873-878.

Zervas, G. \& Tsiplakou, E., 2012. An assessment of GHG emissions from small ruminants in comparison with GHG emissions from large ruminants and monogastric livestock. Atmospheric Environ. 49, 13-23.

\section{Appendix A}

Table A.1 Swine intake, diet composition and digestibility data (SAPPO*, 2011)

\begin{tabular}{lcccccc}
\hline \multirow{2}{*}{ Pig activity data } & \multicolumn{2}{c}{ Intake (kg/day) } & $\begin{array}{c}\text { Gross } \\
\text { energy } \\
\text { intake } \\
\text { (MJ/day) }\end{array}$ & $\begin{array}{c}\text { Crude } \\
\text { protein } \\
\text { concentration } \\
\%\end{array}$ & $\begin{array}{c}\text { Dry matter } \\
\text { digestibility } \\
\%\end{array}$ & $\begin{array}{c}\text { Digestible } \\
\text { energy } \\
\text { concentration } \\
\text { (MJ/kg) }\end{array}$ \\
\cline { 2 - 6 } Commercial & Communal & & & & \\
Boars & 2.2 & 1.8 & 33.21 & 13 & 92 & 13 \\
Dry gestating sows & 2.5 & 2.0 & 36.9 & 14 & 92 & 13 \\
Lactating sows & 4.75 & 3.8 & 70.11 & 13 & 92 & 13.5 \\
Replacement sows & 2.8 & 2.24 & 41.33 & 16 & 92 & 13.2 \\
Replacement boars & 2.8 & 2.24 & 41.33 & 16 & 92 & 13.2 \\
Pre-wean piglets & 0.5 & 0.4 & 7.38 & 18 & 92 & 14.5 \\
Cull sows & 1.8 & 1.44 & 26.57 & 14 & 92 & 13 \\
Cull boars & 2.2 & 1.8 & 33.21 & 13 & 92 & 13 \\
Porkers & 2.4 & 1.92 & 35.42 & 18 & 92 & 14 \\
Baconers & 2.8 & 2.24 & 41.33 & 18 & 92 & 14 \\
\hline
\end{tabular}

* South African Pork Producers Organisation.

Table A.2 Enteric methane emissions (kg/head/year) (ANIR, 2009)

\begin{tabular}{ll}
\hline Source & MEF (kg/head/year) \\
\hline Horses & 18 \\
Donkeys and mules & 10 \\
Ostriches & 5 \\
Chickens and other poultry & Not estimated by IPCC (1997) \\
\hline
\end{tabular}

MEF: methane emission factor.

Table A.3 Allocation of manure to manure management system (MMS) (\%)

\begin{tabular}{lccccc}
\hline & Lagoon & Liquid/slurry & Drylot & Daily spread & Digester \\
\hline Commercial pigs & 92 & 1.5 & 5 & 1.5 & 0 \\
Communal pigs & 0 & 0 & 50 & 50 & 0 \\
Horses & 0 & 0 & 40 & 60 & 0 \\
\hline
\end{tabular}


Table A.4 Methane conversion factors (MCF), (\%) of different manure management systems (ANIR, 2009)

\begin{tabular}{lccccc}
\hline & Lagoon & Liquid/ slurry & Drylot & Daily spread & Digester \\
\hline MCF & 90 & 35 & 1.5 & 0.5 & 10 \\
\hline
\end{tabular}

Table A.5.1 Other monogastric livestock - enteric fermentation emission factors ( $\mathrm{kg} \mathrm{CH}_{4} /$ head/year) (ANIR, 2009)

\begin{tabular}{lcccc}
\hline & Horses & Donkeys \& Mules & Ostriches & Poultry \\
\hline All provinces & 18 & 10 & 5 & N.A \\
\hline
\end{tabular}

Table A.5.2 Other monogastric livestock - manure production (kg DM/head/year) (ANIR, 2009)

\begin{tabular}{lccc}
\hline & Horses & Donkeys \& Mules & Ostriches \\
\hline All provinces & 957 & 319 & 114 \\
\hline
\end{tabular}

Table A.5.3 Other monogastric livestock - nitrogen excretion factors (kg N/head/year) (ANIR, 2009)

\begin{tabular}{lccccc}
\hline & Horses & Donkeys \& Mules & Ostriches & Poultry - Broilers & Poultry - Layers \\
\hline All provinces & 39.5 & 13.2 & 7 & 0.7 \\
\hline
\end{tabular}

Table A.6.1 Pigs - nitrogen (kg/head/year) entering the manure management system (MMS) (ANIR, 2009)

\begin{tabular}{lc}
\hline Breeding herd & Pig - kg N in MMS \\
\hline Boars & 14.59 \\
Dry gestating sows & 20.7 \\
Lactating sows & 20.7 \\
Replacement sows & 12.23 \\
Replacement boars & 12.23 \\
Pre-wean piglets & 11.04 \\
Cull sows & 20.7 \\
Cull boars & 14.59 \\
Porkers (70 kg) & 11.04 \\
Baconers $(90 \mathrm{~kg})$ & 11.04 \\
\hline
\end{tabular}

Table A.6.2 Pigs - allocation of manure to manure management systems and nitrogen emissions factor $\left(\mathrm{N}_{2} \mathrm{O}-\mathrm{N} / \mathrm{kg} \mathrm{N}\right.$ excreted)

\begin{tabular}{lc}
\hline & Nitrogen emissions factor \\
\hline & \\
Lagoon & 0.001 \\
Liquid/ slurry & 0.001 \\
Drylot & 0.02 \\
Daily spread & 0 \\
Digester & 0.001 \\
\hline
\end{tabular}

